\title{
SPECTROPHOTOMETRIC DETERMINATION OF FLUOTHANE VAPOUR
}

\section{Werner Kalow, M.D."}

IN THE ORgGinal EXPERIMENTAL wORK on Fluothane reported by Raventos (1), the vapour concentration was controlled by a dropwise addition of mercury into liquid Fluothane, thereby causing an overflow of known volume which was immediately vapourized. Later, Raventos (2) introduced a trichloroethylene bottle from a Boyle's apparatus. It was fitted with an extended scale to control the concentration of Fluothane vapour for anaesthesia. E. Falkner Hill (3) measured the output of this and a similar apparatus by weighing the Fluothane vapour. He pointed out that the concentration of Fluothane vapour decreased during the application, even if the valve setting remained unaltered, owing to the fall of temperature caused by the evaporation of Fluothane. A temperaturecompensated vaporizer (Fluotec) has been constructed since. However, a rapid means of measuring directly the concentration of Fluothane in an anaesthetic gas mixture is still needed, particularly during closed-crrcuit anaesthesia. Therefore, we have measured the spectra of Fluothane in order to see whether optical methods can be used. Sutable absorption was found in the ultraviolet as well as in the infrared ranges. The ultraviolet absorption was then used for some measures of concentration.

\section{Methods}

The spectra were measured with two Beckman Recording Spectrophotometers: Model DK2 was used throughout the ultraviolet, visible, and near-infrared region, Model IR4 was used to record the near-infrared and infrared spectra. The measurements from the two instruments overlapped in the range between 1.0 and 2.8 microns.

The absorption cells used for the determination of the spectra had a light path of $10 \mathrm{~cm}$. Liquid Fluothane was introduced into the cells where it evaporated while the cells were closed. For measurements in the infrared, the cells contained only traces of air besides the Fluothane vapour. The ultraviolet spectrum was determined in air. The report on the intensity of the infrared absorption may be regarded as semi-quantitative. The measurements in the ultraviolet were repeated until reproducibility of the data was established. That is, even with great variations of technique, the spectrum was reproducible within \pm 1.5 per cent.

The absorption cell used for checking the output of an anaesthetic machine had a light path of $10 \mathrm{~mm}$. It was a silica cell of the type commonly used in Beckman Spectrophotometers, that is, it measured $1 \times 1 \times 4 \mathrm{~cm}$. A tightly fitting cover for the cell was cut from plexiglass. Two small holes of about $1 \mathrm{~mm}$. diameter were drilled into corners of the cover. Into these holes, two pieces of plastic tubing fitted closely. Both piecés were roughly 5 inches long. One piece of

'Department of Pharmacology University of Toronto. 
tubing was pushed far enough through the hole to haver its opening near the bottom of the cell, the other piece of tubing went just through the cover so as to have its opening near the top of the cell. As long as the tubing does not come close to the centre of the absorption cell, it does not interfere with the beam of light passing through the cell. The cell is placed into the spectrophotometer, the two pieces of tubing sticking out. The cell can then be flushed with gas. If there is enough gas available, and if the optical measurements are done while the flushing proceeds, small leaks in the system are immaterial.

Plastic bags developed for breath samples containing alcohol (4) were used for transporting samples from the operating room to the laboratory. These containers consisted of an upper end of a one-pound ether tin; a Saran bag ${ }^{1} 5$ inches wide and 12 inches deep was fitted snugly over the cut-off end of the tin where it was tightened with adhesive. Fluothane vapour disappeared very slowly from these containers; a 50 per cent drop of its concentration took 26 hours.

With the aid of adapters, such a contaner could be connected with the absorption cell. By pressing the Saran bag, the gas sample was flushed through the cell. After a minute of flushing with roughly $100 \mathrm{ml}$. of gas, the optical measurements were made.

\section{Results}

The essential parts of the absorption spectra of Fluothane vapour are demonstrated in Figure 1. The greatest absorption occurs in the ultraviolet. There are numerous other peaks of absorption in the infrared which are not presented because they are small in comparison with those shown. Most of the omitted peaks lie between 1.6 and 7 microns. There was no absorption between 1.6 and 0.27 microns ( $=270$ millimicrons). This includes the visible range.
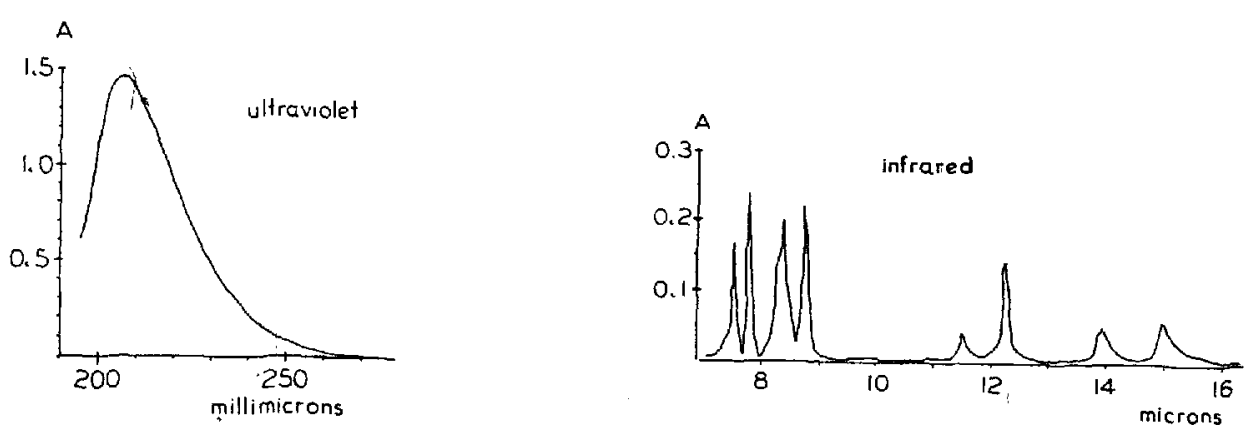

FIGURE 1. Ultraviolet and infrared absorption spectra of Fluothane vapour. Wave-lengths are given in millimicrons and microns. The letter A stands for Absorbance (formerly called optical density). Note the difference between the absorbance scales of the two graphs. The concentration of Fluothane vapour was $100 \mathrm{mg} . / 1$. The absorption cells had a light path of $10 \mathrm{~cm}$.

${ }^{1}$ The bags were obtained from Mastex Ltd., 41 Torbarrie St., Toronto. The material was designated as " 100 gauge double wound Saran." The bags were kindly mounted and checked by Mr. H. Salem. 
The data are presented as mg. per litre because this is a measure independent of temperature and pressure. According to the definitions and figures of Hill (3), $100 \mathrm{mg}$./ 1 corresponds to a concentration of 1.13 per cent. This measure of volume of vapour per volume of gas is the one most frequently used in practice. On this scale, the ultraviolet absorbance in a cell with $1 \mathrm{~cm}$. light path of a gas, containing 1 per cent Fluothane, is 0.050 at $228 \mu, 0.081$ at $220 \mu$, or 0.141 at $206 \mu$.

Measurements at $228 \mu$ need very little arithmetic for their interpretation. Furthermore, at this wave-length there is no interference with the measurements from anaesthetic gases. Nitrous oxide has an ultraviolet absorbance at shorter wave-length. Air or oxygen do not interfere at $\mathrm{cll}$ in the indicated range.

Some analytical data obtained by ultraviolet spectrophotometry are shown in Table I. The output from a temperature-compensated vaporizer (TN Fluotec) was checked. The apparatus delivers very nearly the expected concentrations, apparently independent of the rate of gas How. However, a slight drop of the output seems to have taken place during the seven minutes of sampling.

\section{TABLE I}

Output of a Temperature-Compensated Vaporizer (Fluotec) Measured by Ultraviolet SPECTROPHOTOMETRY

\begin{tabular}{ccccc}
\hline $\begin{array}{c}\text { Time of } \\
\text { sampling } \\
\text { (P.M.) }\end{array}$ & $\begin{array}{c}\text { Rate of } \\
\text { flow in } \\
\text { 1./min. }\end{array}$ & $\begin{array}{c}\text { Expected } \\
\text { concentration of } \\
\text { Fluothane } \\
(\%)\end{array}$ & $\begin{array}{c}\text { Observed } \\
\text { concentration of } \\
\text { Fluothane } \\
(\%)\end{array}$ & $\begin{array}{c}\text { Observed } \\
\text { as \% of } \\
\text { expected }\end{array}$ \\
\hline $3: 18$ & 10 & 0.5 & 0.48 & 96 \\
$3: 19$ & 10 & 1.0 & 0.85 & 85 \\
$3: 20$ & 10 & 1.5 & 1.46 & 97 \\
$3: 21$ & 10 & 2.0 & 1.93 & 90 \\
$3: 22$ & 6 & 2.0 & 1.80 & 78 \\
$3: 23$ & 6 & 0.5 & 0.39 & 80 \\
$3: 25$ & 12 & 1.0 & 0.80 & 80 \\
\hline
\end{tabular}

*The gas mixture was 50 per cent nitrous oxide in oxygen.

\section{Discussion}

The properties of Fluothane are such that both ultraviolet and infrared radiation can be used for its demonstration. The choice depends on the availability of equipment. If a device is to be especially designed for monitoring the concentration of Fluothane during anaesthesia, utilization of the infrared absorption should be chosen. Simplicity and relative economy of the design can be achieved which is not possible in the ultraviolet. It is to be expected that commercial apparatus will soon be made available for this purpose. On the other hand, many laboratories are presently equipped for ultraviolet spectrophotometry, which has become widespread because of many other well-known biological applications. It has been shown that such available equipment is suitable for measurements of the concentration of Fluothane vapour. 


\section{SUMMARY}

The optical properties of Fluothane vapour have been determined. There was a strong absorption of ultraviolet and infrared radiation. While the absorption in either range can be used to measure the concentration of Fluothane, quantitative data have been given only for the use of ultraviolet spectrophotometry. The construction of a suitable abscrption cell, and a container in which Fluothane vapour can be transported, have been described.

\section{ACKNOWLEDGMENTS}

Dr. H. Cullumbine, Department of Pharmacology, and Dr. S. M. Campbell, Department of Anaesthesia, University of Toronto, suggested the problem to me. The anaesthetic apparatus was checked in co-operation with Dr. I. M. MacKay of the Department of Anaesthesia. Dr. G. F. Wright, Department of Chemistry, permitted the use of the infrared spectrophotometer.

\section{RÉSUMÉ}

On a fixé les propriétés optiques de la vapeur de Fluothane. On a noté une forte absorption de radiation ultraviolette et infrarouge. Bien que l'absorption dans les deux zones puisse servir à mesurer la concentration de fluothane, les données quantitatives ont été obtenues seulement avec l'emploi de la spectrophotométrie à l'ultraviolet. On décrit la construction d'une cellule d'absorption appropriée et un contenant dans lequel la vapeur de Fluothane peut être introduite.

\section{REFERENCES}

1. Raventos, T. The Action of Fluothane. A New Volatile Anaesthetic Brit. J. Pharmacol. 11. 394-409 (1956).

2. Raventos, T. 'The Action of "Fluothane" A New Non-Inflammable Volatile Anaesthetic Report at the 20th Internat. Physiol Congr, Abstracts of Communications, pp. 754-75 (1956).

3. Hill, E. Falkner. Percentages of Fluothane Vapour Delivered from a Trilene Bottle. Brit J Anaesth. 29. 12-16 (1957).

4 Kalow, W, Lucas, G. H. W., \& MCColl, J. D. Contaners for Breath Samples for Alcohol Analysis. Proc, 2nd Internat. Conf. on Alcohol \& Road Traffic, pp. 137-8. Toronto (1955). 